\title{
Uso da Terra no Entorno do PARNA-Caparaó: Preocupação com Incêndios Florestais
}

\author{
Sâmia D’angelo Alcuri Gobbo ${ }^{1}$, Ricardo Ferreira Garcia², \\ Atanásio Alves do Amaral ${ }^{1}$, Fernando Coelho Eugenio ${ }^{3}$, \\ Célio Ricardo da Silva Alvarez ${ }^{1}$, Alixandre Sanquetta Laporti Luppi ${ }^{4}$
}

\author{
${ }^{1}$ Instituto Federal do Espírito Santo - IFES, Alegre/ES, Brasil \\ ${ }^{2}$ Centro de Ciências e Tecnologias Agropecuárias, Universidade Estadual Norte Fluminense Darcy Ribeiro - UENF, \\ Goyacazes/RJ, Brasil \\ ${ }^{3}$ Departamento de Ciências Florestais e da Madeira, Universidade Federal do Espírito Santo - UFES, \\ Jerônimo Monteiro/ES, Brasil \\ ${ }^{4}$ Departamento de Engenharia Agrícola, Universidade Federal de Viçosa - UFV, Viçosa/MG, Brasil
}

\begin{abstract}
RESUMO
Considerando que o modo de ocupação das áreas agrícolas apresenta grande influência no risco de ocorrência de incêndios florestais, o objetivo deste estudo foi fotointerpretar o uso e ocupação da terra no entorno do Parque Nacional do Caparaó (PARNA-Caparaó), face capixaba, e analisar a ocorrência de focos de calor na área. Foi fotointerpretada no total uma área de $654,95 \mathrm{~km}^{2}$, dos quais $7,88 \mathrm{~km}^{2}$ cobertos por eucalipto, $89,10 \mathrm{~km}^{2}$, por fragmentos florestais, $314,60 \mathrm{~km}^{2}$, por pastagens, 13,03 km², por reflorestamento de espécies nativas, $180,60 \mathrm{~km}^{2}$, por café e $49,74 \mathrm{~km}^{2}$, por outros usos. Há uma área relevante ocupada por reflorestamento em todos os municípios avaliados da zona de amortecimento do PARNA-Caparaó, quando comparada a outros estudos. Os focos de calor, em sua maioria, aconteceram em beiras de estradas, pastagens, capoeiras e próximo a fragmentos florestais.
\end{abstract}

Palavras-chave: áreas de preservação, focos de calor, geotecnologias.

\section{Land Use in the Surroundings of PARNA-Caparaó National Park: Preoccupation with Forest Fires}

\begin{abstract}
As the occupation of agricultural areas is extremely important in assessing the fire risk, the objective of this study was to photo-interpret the land use and occupation of the surroundings of Caparaó National Park (PARNA-Caparaó), on its area facing Espirito Santo state, and analyze forest fire occurrence in the region. Photo-interpretation was conducted on a total area of $654.95 \mathrm{~km}^{2}$ comprising $7.88 \mathrm{~km}^{2}$ of eucalyptus, $89.10 \mathrm{~km}^{2}$ of forest fragment, $314.60 \mathrm{~km}^{2}$ of grassland, $13.03 \mathrm{~km}^{2}$ of reforestation of native species, $180.60 \mathrm{~km}^{2}$ of coffee, and $49.74 \mathrm{~km}^{2}$ of other uses. There is a relevant area occupied by reforestation in all the municipalities evaluated in the buffer zone of PARNA-Caparaó National Park compared with that of other studies. Forest fires have occurred mostly on roadsides, pastures, shrubbery areas, and around forest fragments.
\end{abstract}

Keywords: preservation areas, heat spots, geotechnology. 


\section{INTRODUÇÃO}

A análise do uso e ocupação da terra atrelada ao planejamento e gestão visa compreender a dinâmica de ocupação de uma determinada região e estabelecer diretrizes que garantam a qualidade de vida da população e a manutenção dos recursos naturais de forma sustentável. Tal análise é fundamental para a compreensão dos padrões de organização do espaço e para a gestão ambiental, ante a forma dinâmica com que as inúmeras transformações ocorrem no espaço geográfico.

$\mathrm{Na}$ atualidade, com a intensificação das pressões antrópicas sobre o meio ambiente, observa-se um processo de substituição das paisagens naturais por outros usos e ocupações da terra, além da conversão das áreas com cobertura florestal em fragmentos florestais, causando problemas ao meio ambiente e, em muitos casos, afetando a disponibilidade de recursos naturais importantes para a população de uma região. Nesse contexto, os incêndios florestais têm sido um dos principais agentes de degradação de fragmentos florestais, tanto pela destruição direta quanto pelas alterações na dinâmica dos ecossistemas afetados (Santos et al., 2010).

Os incêndios florestais são uma realidade em todo o mundo. São complexos, diferentes e, muitas vezes, difíceis de serem combatidos em função das características de cada área. Como as principais causas de incêndios normalmente estão relacionadas com a atividade do homem (Medeiros, 2002; Medeiros \& Fiedler, 2004; Fiedler et al., 2006), elas podem ser evitadas por meio de programas de prevenção. A caracterização criteriosa das atividades de uso e ocupação da terra pelo homem, relacionando-as com o potencial de produção de fontes de ignição, é fator fundamental para o zoneamento de risco de incêndios (Batista, 2000).

A preocupação com a incidência de incêndios nos parques nacionais carece de maior aprofundamento dos estudos. Fórmulas para o cálculo da incidência de fogo já foram elaboradas com a intenção de monitorar o manejo da terra. Segundo Sismanoglu \& Setzer (2004), Setzer \& Sismanoglu (2012) e White et al. (2013), o risco de fogo (RF) é um valor numérico obtido através de equações matemáticas que representam a probabilidade de ocorrência de incêndios com base em diversos parâmetros como: número de dias seguidos sem chuva, tipo de vegetação, temperatura do ar e umidade relativa do ar, dentre outros.

As metodologias que utilizam a geotecnologia como ferramenta principal vêm se destacando, sendo a alternativa mais viável para reduzir significativamente o tempo gasto com o mapeamento das áreas a serem protegidas e, por consequência, otimizar o período hábil de fiscalização do cumprimento das obrigações pertinentes à legislação (Eugenio et al., 2011).

Nesse contexto, o Sistema de Informação Geográfica (SIG) constitui ferramenta capaz de simular as funções que representam os processos ambientais em diversas regiões de forma simples e eficiente, permitindo economia de recursos e tempo. Essas manipulações permitem agregar dados de diferentes fontes (imagens de satélite, mapas topográficos, mapas de uso e ocupação da terra, entre outros) em diferentes escalas. O resultado dessas operações geralmente é apresentado sob a forma de mapas temáticos com as informações desejadas (Mendes, 1996).

Diante do exposto, o trabalho teve como objetivo fotointerpretar e mapear as classes ambientais de uso e ocupação da terra na zona de amortecimento do Parque Nacional do Caparaó, face capixaba, e avaliar a localização dos focos de calor nos anos de 2008, 2009 e 2010 na área de estudo.

\section{MATERIAL E MÉTODOS}

O presente trabalho foi desenvolvido na zona de amortecimento do PARNA-Caparaó, dentro de seus limites no estado do Espírito Santo, entre os paralelos $20^{\circ} 15^{\prime} \mathrm{S}$ e $20^{\circ} 37^{\prime} \mathrm{S}$ e os meridianos $41^{\circ} 43^{\prime} \mathrm{W}$ e $41^{\circ} 53^{\prime} \mathrm{W}$ (Figura 1).

A Serra do Caparaó é uma das mais representativas áreas de preservação da Mata Atlântica em território capixaba. O parque possui uma fitofisionomia singular de campos de altitude (tipo de vegetação peculiar, cujas características são fortemente influenciadas pelas condições de solo, clima e altitude do maciço do Caparaó) e constitui relevante patrimônio geológico, além de proteger nascentes de três importantes bacias hidrográficas (rios Itabapoana, Itapemirim e Doce) e diversas espécies endêmicas da fauna e flora ameaçadas de extinção (ICMBio, 2015).

Foi realizada a fotointerpretação das classes ambientais de uso e ocupação da terra para a área de 


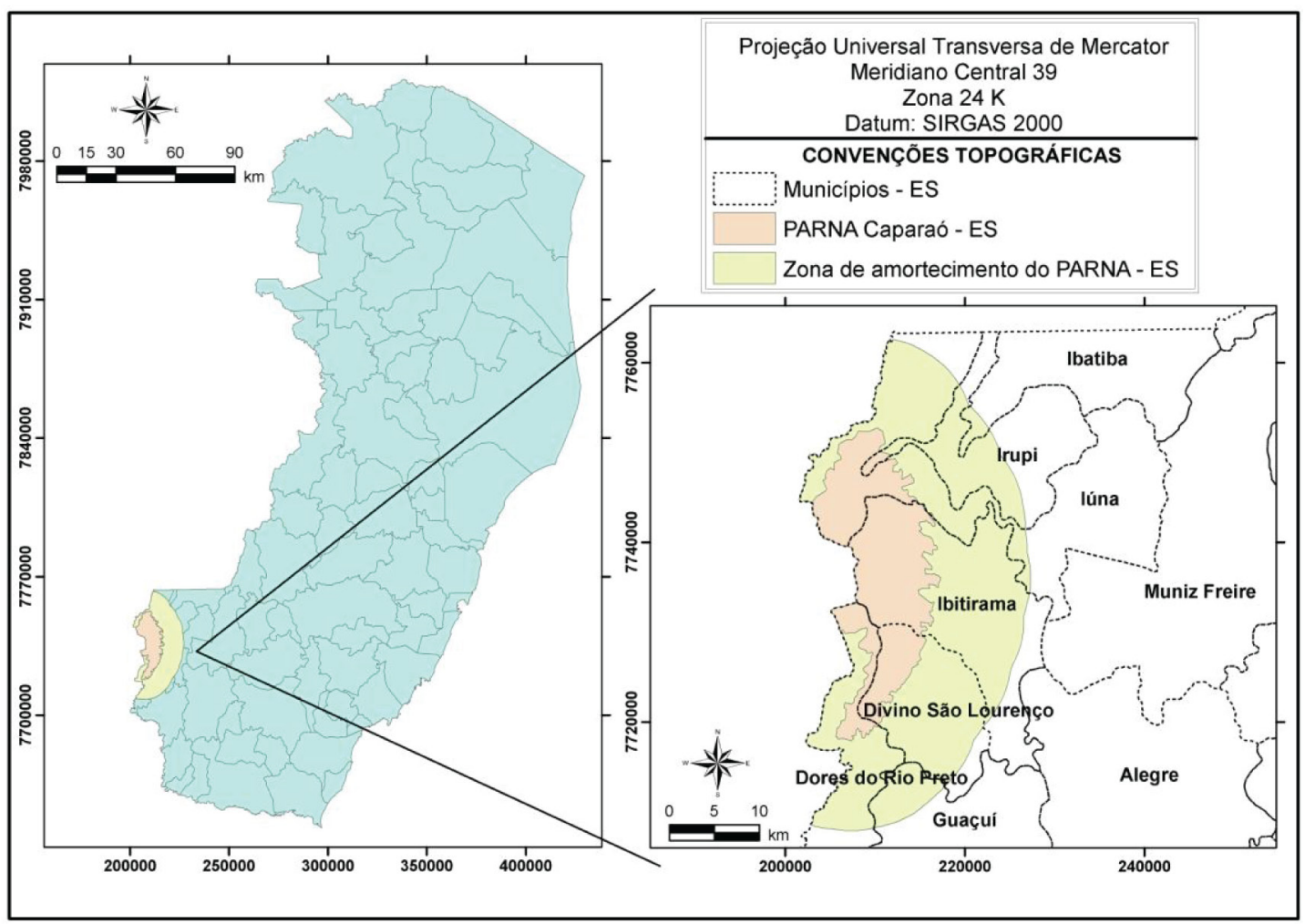

Figura 1. Localização do PARNA-Caparaó no Espírito Santo.

Figure 1. PARNA-Caparaó location in Espírito Santo state.

amortecimento do Parque Nacional do Caparaó, face capixaba, utilizando-se aerofotos digitais ortorretificadas de junho de 2007, na escala 1:35.000, com resolução espacial de $1,1 \mathrm{~m}$, nos intervalos espectrais do visível $(0,45-0,69 \mu \mathrm{m})$ disponibilizadas pelo Instituto Estadual de Meio Ambiente e Recursos Hídricos - IEMA. A digitalização em tela das classes ambientais de uso e ocupação da terra foi feita na escala padrão de 1:2.000, utilizando-se o aplicativo computacional ArcGIS, sendo elaborado um arquivo vetorial poligonal para cada uma delas.

As classes de uso e ocupação da terra digitalizadas e processadas foram: 1 - eucalipto, 2 - fragmento florestal, 3 - pastagem, 4 - reflorestamento de espécies nativas, 5 - café, 6 - outros. A classe "outros" abrange as seguintes categorias encontradas na área de estudo: área agrícola, área edificada, área urbana, campo sujo, corpos d'água, formação rochosa, reservatório, solo exposto, capoeira e várzea.

O fluxograma com as etapas da metodologia utilizada para o mapeamento das classes ambientais de uso e ocupação da terra está apresentado na Figura 2.
Foi utilizado o shapefile dos focos de calor ocorridos no triênio 2008-2010, disponibilizado no site do Instituto Nacional de Pesquisas Espaciais (INPE), para avaliar e discutir a localização dos incêndios florestais na área de estudo. $\mathrm{O}$ triênio escolhido se destacou pela alta incidência de focos de calor em relação aos demais anos. Os dados foram processados com o auxílio do aplicativo computacional ArcGIS, versão 10.1, módulos ArcMap e ArcInfo Workstation (ESRI, 2012).

\section{RESULTADOS E DISCUSSÃO}

\subsection{Fotointerpretação da área de estudo}

A fotointerpretação resultou em um arquivo shapefile contendo 15.235 polígonos, totalizando uma área de $654,95 \mathrm{~km}^{2}$, dos quais $7,88 \mathrm{~km}^{2}$ cobertos por eucalipto, $89,10 \mathrm{~km}^{2}$, por fragmentos florestais, $314,60 \mathrm{~km}^{2}$, por pastagens, $13,03 \mathrm{~km}^{2}$, por reflorestamento, $180,60 \mathrm{~km}^{2}$, por café e $49,74 \mathrm{~km}^{2}$ foram incluídos na categoria "outros" (Tabelas 1 e 2). 
O município de Iúna apresentou maior área de fragmentos florestais e de lavouras de café, que ocupavam, respectivamente, $27,85 \mathrm{~km}^{2}$ e $44,75 \mathrm{~km}^{2}$ da área. Esse município caracteriza-se por ser um dos maiores produtores de café arábica do Espírito Santo. O município de Ibitirama, que possui maior área dentro da zona de amortecimento do PARNA-Caparaó, com $162,59 \mathrm{~km}^{2}$, apresentou maior área de pastagens, $85,07 \mathrm{~km}^{2}$.

Divino de São Lourenço apresentou maior área de eucaliptos, com $3,36 \mathrm{~km}^{2}$, e reflorestamento de espécies nativas, com $3,27 \mathrm{~km}^{2}$ de área. Embora Ibatiba apresente apenas $4,89 \mathrm{~km}^{2}$ de plantação de café, proporcionalmente é o município com maior

Tabela 1. Dimensões das classes ambientais de uso e ocupação da terra para a zona de amortecimento do PARNA-Caparaó, face capixaba.

Table 1. Dimensions of the environmental classes of land use and occupation for the capixaba side of the Caparaó National Park buffer zone.

\begin{tabular}{lrcc}
$\begin{array}{l}\text { Uso e ocupação } \\
\text { da terra }\end{array}$ & $\begin{array}{r}\text { Área } \\
\left(\mathbf{k m}^{2}\right)\end{array}$ & $\begin{array}{c}\text { Perímetro } \\
(\mathbf{k m})\end{array}$ & $\begin{array}{c}\text { Porcentagem } \\
\mathbf{( \% )}\end{array}$ \\
\hline Eucalipto & 7,88 & 135,54 & 1,20 \\
$\begin{array}{l}\text { Fragmentos } \\
\text { florestais }\end{array}$ & 89,10 & 2030,72 & 13,60 \\
\hline Pastagem & 314,60 & 4548,38 & 48,03 \\
Reflorestamento & 13,03 & 324,93 & 1,99 \\
Outros & 49,74 & 1788,77 & 7,59 \\
Café & 180,60 & 3364,50 & 27,57 \\
Total & 654,95 & $12.192,84$ & $100,00 \%$ \\
\hline
\end{tabular}

área plantada, sendo que em seu território esse cultivo ocupa 50,69\% do solo. Na Figura 3 são apresentadas as classes ambientais de uso e ocupação da terra, na qual se observa o predomínio de áreas de pastagem e cultura cafeeira.

Os fragmentos florestais encontraram-se principalmente nas bordas do limite norte da zona de amortecimento

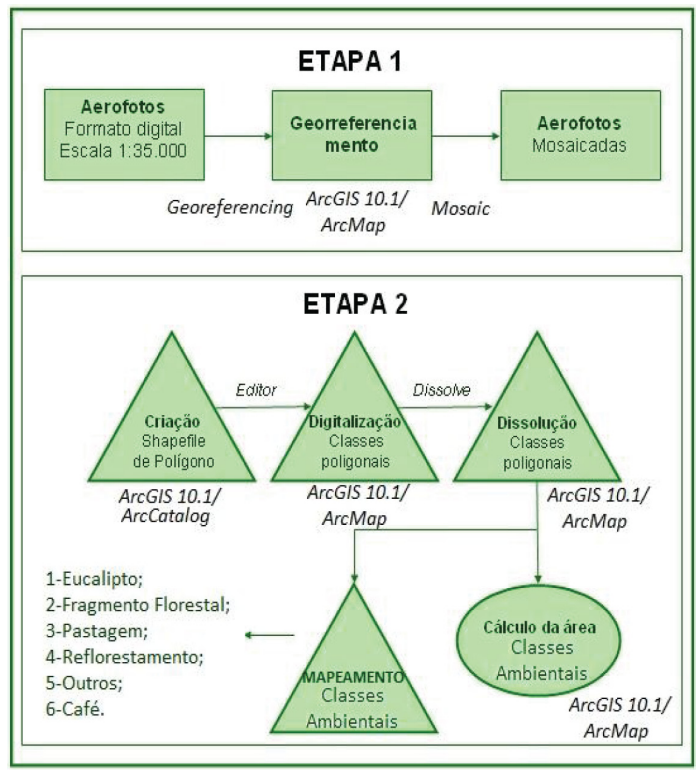

Figura 2. Etapas da metodologia utilizada para o mapeamento das classes ambientais de uso e ocupação da terra na zona de amortecimento do PARNA-Caparaó. Figure 2. Methodology used for mapping the environmental classes of land use and occupation for the PARNA-Caparaó buffer zone.

Tabela 2. Dimensões das classes ambientais de uso e ocupação da terra entre os municípios que fazem parte da zona de amortecimento do PARNA-Caparaó, face capixaba.

Table 2. Dimensions of environmental classes of land use and occupation among the municipalities in the buffer zone of the Caparaó National Park capixaba side.

\begin{tabular}{|c|c|c|c|c|c|c|c|c|c|c|c|c|}
\hline \multirow{3}{*}{ Localidade } & \multicolumn{12}{|c|}{ Uso e ocupação da terra } \\
\hline & \multicolumn{2}{|c|}{ Eucalipto } & \multicolumn{2}{|c|}{$\begin{array}{c}\text { Fragmentos } \\
\text { florestais }\end{array}$} & \multicolumn{2}{|c|}{ Pastagem } & \multicolumn{2}{|c|}{ Reflorestamento } & \multicolumn{2}{|c|}{ Café } & \multicolumn{2}{|c|}{ Outros } \\
\hline & $\mathrm{km}^{2}$ & $\%$ & $\mathrm{~km}^{2}$ & $\%$ & $\mathrm{~km}^{2}$ & $\%$ & $\mathrm{~km}^{2}$ & $\%$ & $\mathbf{k m}^{2}$ & $\%$ & $\mathrm{~km}^{2}$ & $\%$ \\
\hline $\begin{array}{l}\text { Divino de São } \\
\text { Lourenço }\end{array}$ & 3,36 & 2,87 & 15,39 & 13,16 & 68,64 & 58,68 & 3,27 & 2,80 & 18,30 & 15,64 & 8,02 & 6,86 \\
\hline $\begin{array}{l}\text { Dores do Rio } \\
\text { Preto }\end{array}$ & 0,59 & 0,64 & 11,34 & 12,29 & 48,37 & 52,41 & 2,67 & 2,89 & 22,51 & 24,39 & 6,82 & 7,39 \\
\hline Guaçuí & 0,03 & 0,09 & 2,95 & 8,52 & 21,03 & 60,73 & 0,74 & 2,14 & 7,14 & 20,62 & 2,74 & 7,91 \\
\hline Ibatiba & 0,00 & 0,03 & 0,84 & 8,71 & 3,05 & 31,63 & 0,10 & 1,04 & 4,89 & 50,71 & 0,76 & 7,88 \\
\hline Ibitirama & 1,86 & 1,14 & 21,02 & 12,93 & 85,07 & 52,32 & 2,27 & 1,40 & 44,08 & 27,11 & 8,29 & 5,10 \\
\hline Irupi & 0,47 & 0,58 & 9,71 & 12,02 & 24,02 & 29,74 & 1,37 & 1,70 & 38,93 & 48,20 & 6,27 & 7,76 \\
\hline Iúna & 1,57 & 0,99 & 27,85 & 17,62 & 64,42 & 40,76 & 2,61 & 1,65 & 44,75 & 28,32 & 16,84 & 10,66 \\
\hline TOTAL & 7,88 & 1,20 & 89,10 & 13,60 & 314,60 & 48,03 & 13,03 & 1,99 & 180,60 & 27,57 & 49,74 & 7,59 \\
\hline
\end{tabular}




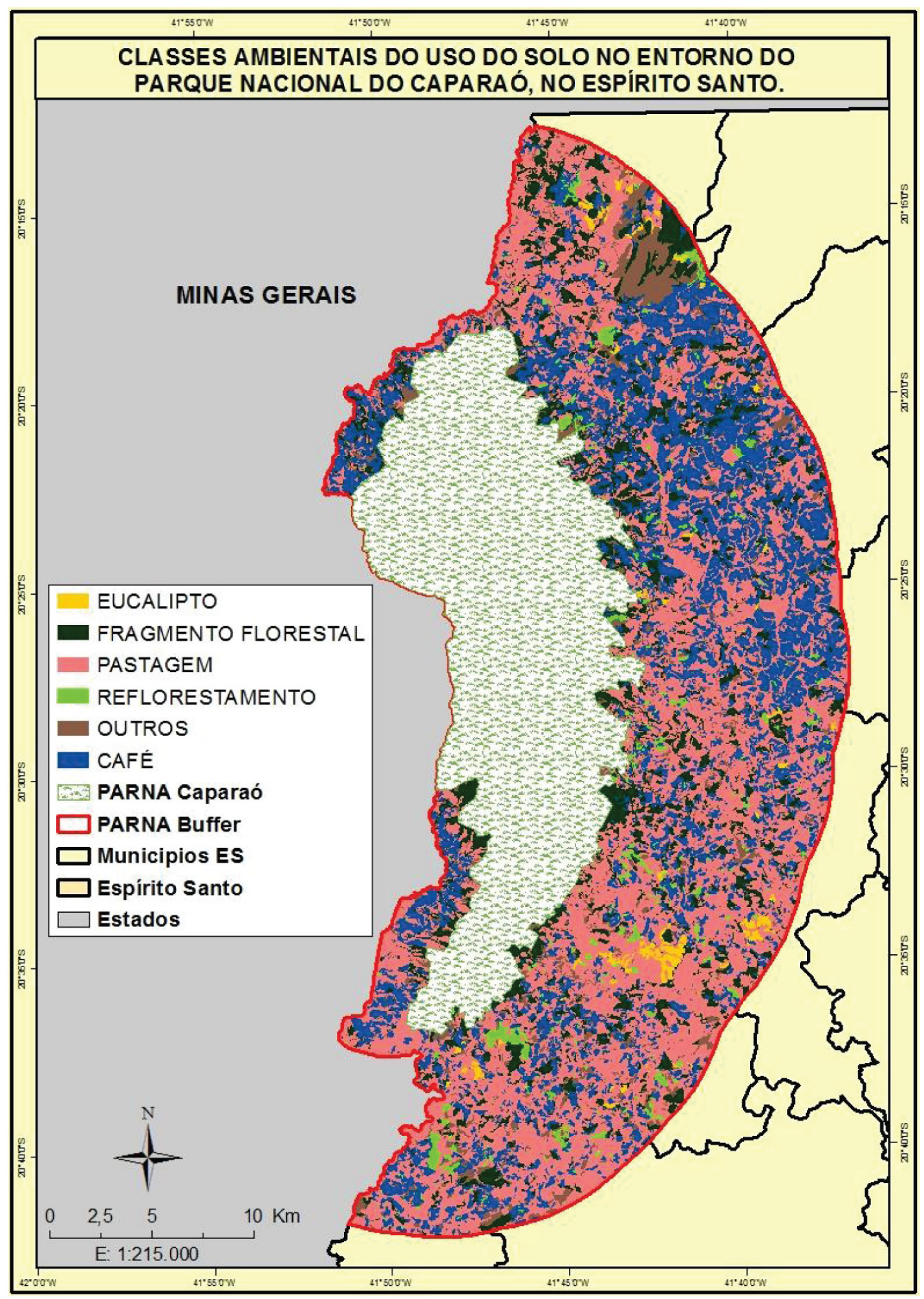

Figura 3. Classes ambientais de uso e ocupação da terra para a zona de amortecimento do PARNA-Caparaó face capixaba.

Figure 3. Environmental Classes of land use and occupation for the buffer zone of Caparaó National Park capixaba side. 
do PARNA-Caparaó, havendo também uma grande concentração de café e de pastagens, que ocupam parte significativa dessa região.

Eugenio et al. (2010), ao caracterizarem uma área no município de Alegre pertencente à microrregião denominada Caparaó Capixaba, no sul do Espírito Santo, constataram que as pastagens ocupam $67,82 \%$ da área estudada, área muito próxima dos valores dos municípios de Divino de São Lourenço e Guaçuí, estudados neste trabalho. Para a classe fragmentos florestais, o autor encontrou 14,39\% de ocupação em relação ao total da área estudada, valor próximo aos encontrados para todos os municípios estudados nesta pesquisa, exceto Guaçuí e Ibatiba, nos quais os fragmentos florestais ocupavam apenas $10 \%$ da área total.

Young (2002) afirma que a demanda por terra para uso pecuário é um dos principais fatores responsáveis pela perda de florestas na Mata Atlântica. Para o autor, a intensificação do desmatamento é resultado das políticas de crédito subsidiado do estado, que vêm incentivando a agropecuária em áreas de floresta. O autor destaca que a expansão das áreas de pastagem ocorreu sobre áreas de lavoura e de formações secundárias, após os anos 1980 .

Percebe-se, nos sete municípios pertencentes à zona de amortecimento do PARNA-Caparaó, um grande percentual de pastagens. Dutra-Lutgens (2000), em seus estudos sobre a caracterização ambiental e subsídios para o manejo da zona de amortecimento da Estação Experimental e Ecológica de Itirapina, SP, observou a substituição das áreas agrícolas temporárias por áreas de pastagens, o que, segundo o autor, indica alteração na economia local. De acordo com esse autor, $42,59 \%$ da área total da zona de amortecimento das áreas protegidas de Itirapina eram ocupadas por pastagens, sendo essa a atividade econômica mais representativa no município estudado.

Silva (2004), utilizando geoprocessamento, identificou as áreas de risco de incêndios florestais, com ênfase na região do Parque Estadual do Itacolomi, Ouro Preto, MG. O autor constatou que nas áreas de campos naturais de altitude houve criação extensiva de gado de corte, sendo essa atividade desenvolvida de forma rudimentar e predatória, baseando-se no aproveitamento do pasto nativo, aliado ao uso do fogo para renovar as gramíneas. Essa prática, tradicional na região, foi transmitida através de várias gerações, sendo uma ameaça aos ecossistemas do Parque Estadual do Itacolomi e adjacências.

Oliveira et al. (2008) identificaram conflitos de uso da terra em Áreas de Preservação Permanente (APP) no Parque Nacional do Caparaó, MG, identificando como principais áreas de conflito de uso e cobertura da terra as classes cafezal $(45,45 \%)$ e pastagem $(31,47 \%)$, grande parte delas localizada em APP, portanto em situação ilegal. Ferrari et al. (2015) encontraram resultado semelhante ao analisar o conflito de uso e cobertura da terra em APP da área do Instituto Federal do Espírito Santo (IFES) - campus de Alegre, onde as pastagens ocupavam $40,35 \%$ da área total do campus e também invadiam as APP. Neste trabalho foi constatado que as áreas de pastagem predominam nos municípios estudados, exceto em Ibatiba e Irupi, onde predominam as lavouras de café. A grande extensão das áreas de pastagem (48,03\% da área estudada) é justificada, pois a pecuária leiteira é uma das principais atividades econômicas da região (Gobbo et al., 2015).

No Brasil, as APP têm sofrido intensa degradação devido às pressões antrópicas sobre o ambiente, observando-se a substituição das paisagens naturais por outros usos e ocupações da terra e a conversão de áreas com cobertura florestal em áreas com fragmentos florestais (Moreira et al., 2015). As atividades agropecuárias constituem uma das principais causas de transformação da paisagem natural e, no caso do Parque Nacional do Caparaó, a expressiva participação das classes cafezal, pastagem e lavouras de subsistência na composição da paisagem ( $77,46 \%$ da área) mostra o intenso processo de antropização sofrido pelo parque (Oliveira et al., 2008). A análise dos conflitos de uso da terra, associada ao planejamento e à gestão, visa a compreensão da dinâmica da região e a elaboração de diretrizes de ocupação que garantam a qualidade de vida da população e a manutenção dos recursos naturais de forma sustentável (Moreira et al., 2015).

\subsection{Análise dos focos de calor}

As Figuras 4, 5 e 6 apresentam os focos de calor na zona de amortecimento do Parque Nacional do Caparaó, face capixaba, para os anos de 2008, 2009 e 2010.

Os focos de calor na área de estudo foram registrados em beiras de estrada, pastagens, capoeiras e próximo a fragmentos florestais. De acordo com Chuvieco \& Congalton (1989), Ferraz \& Vettorazzi (1998) e Almeida (2000), 


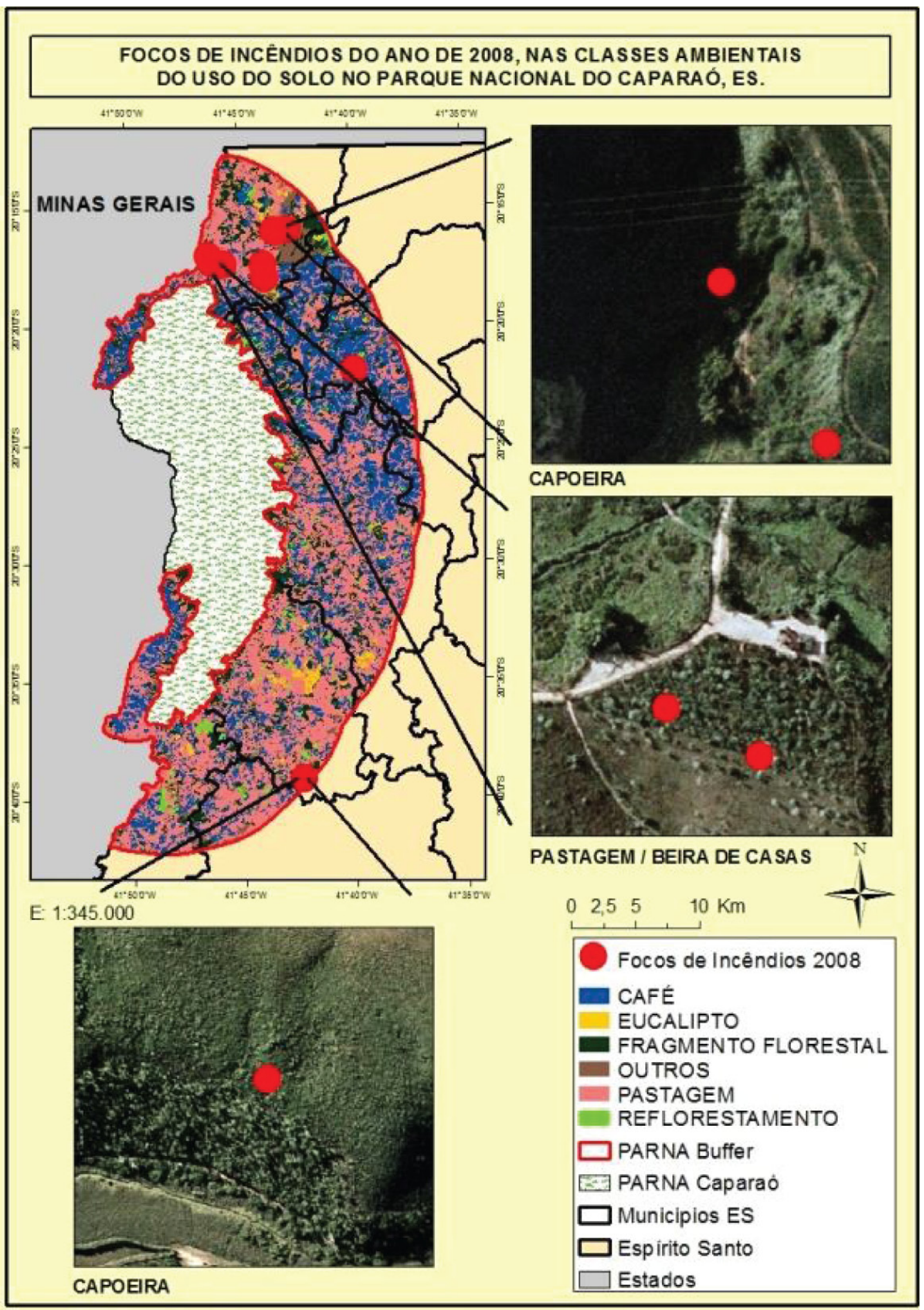

Figura 4. Focos de calor detectados pelo INPE na zona de amortecimento do PARNA-Caparaó, face capixaba, em 2008.

Figure 4. Heat spots detected by INPE in the buffer zone of the Caparaó National Park, capixaba side, in 2008. 


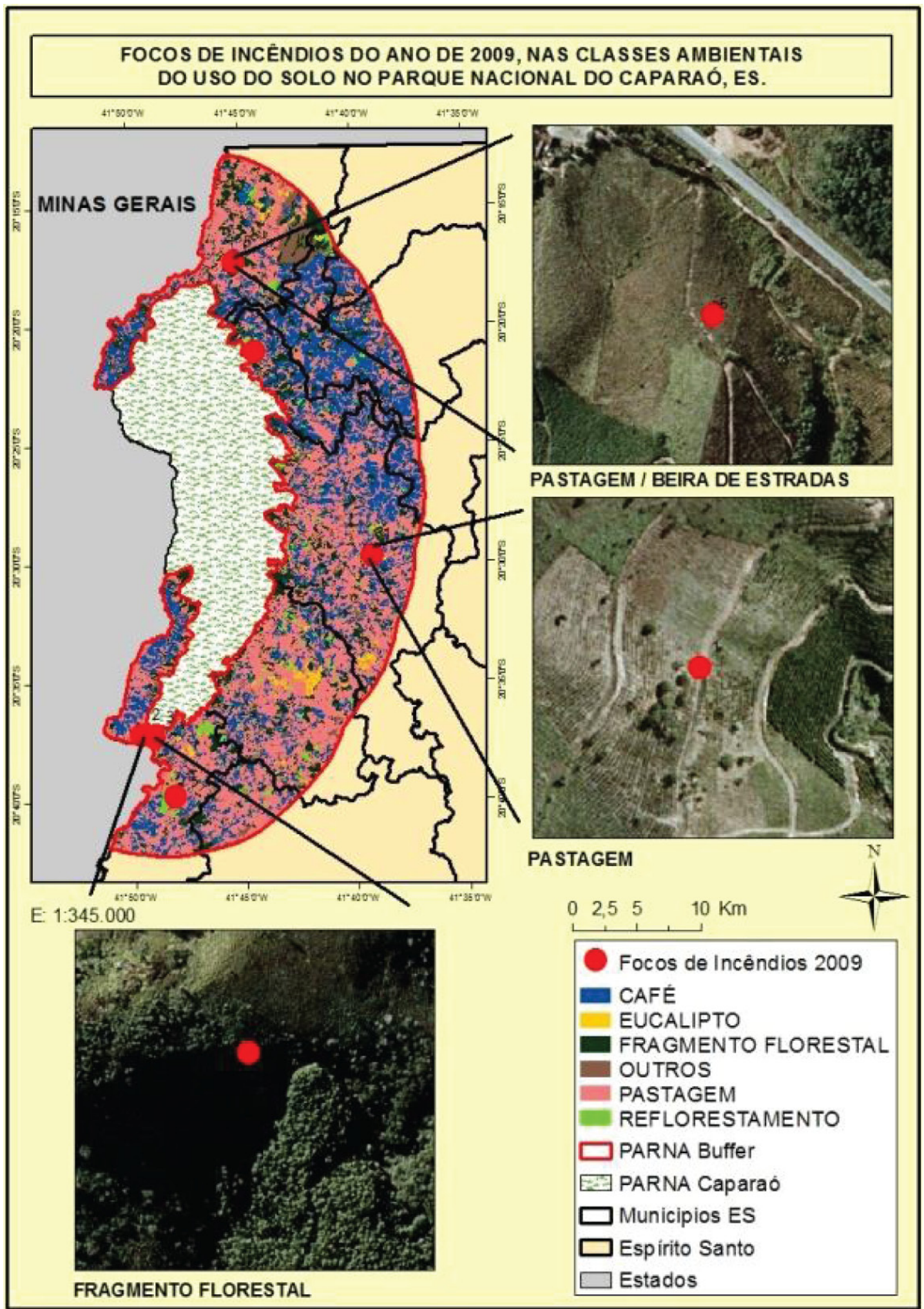

Figura 5. Focos de calor detectados pelo INPE na zona de amortecimento do PARNA-Caparaó, face capixaba, em 2009.

Figure 5. Heat spots detected by INPE in the buffer zone of the Caparaó National Park, capixaba side, in 2009. 


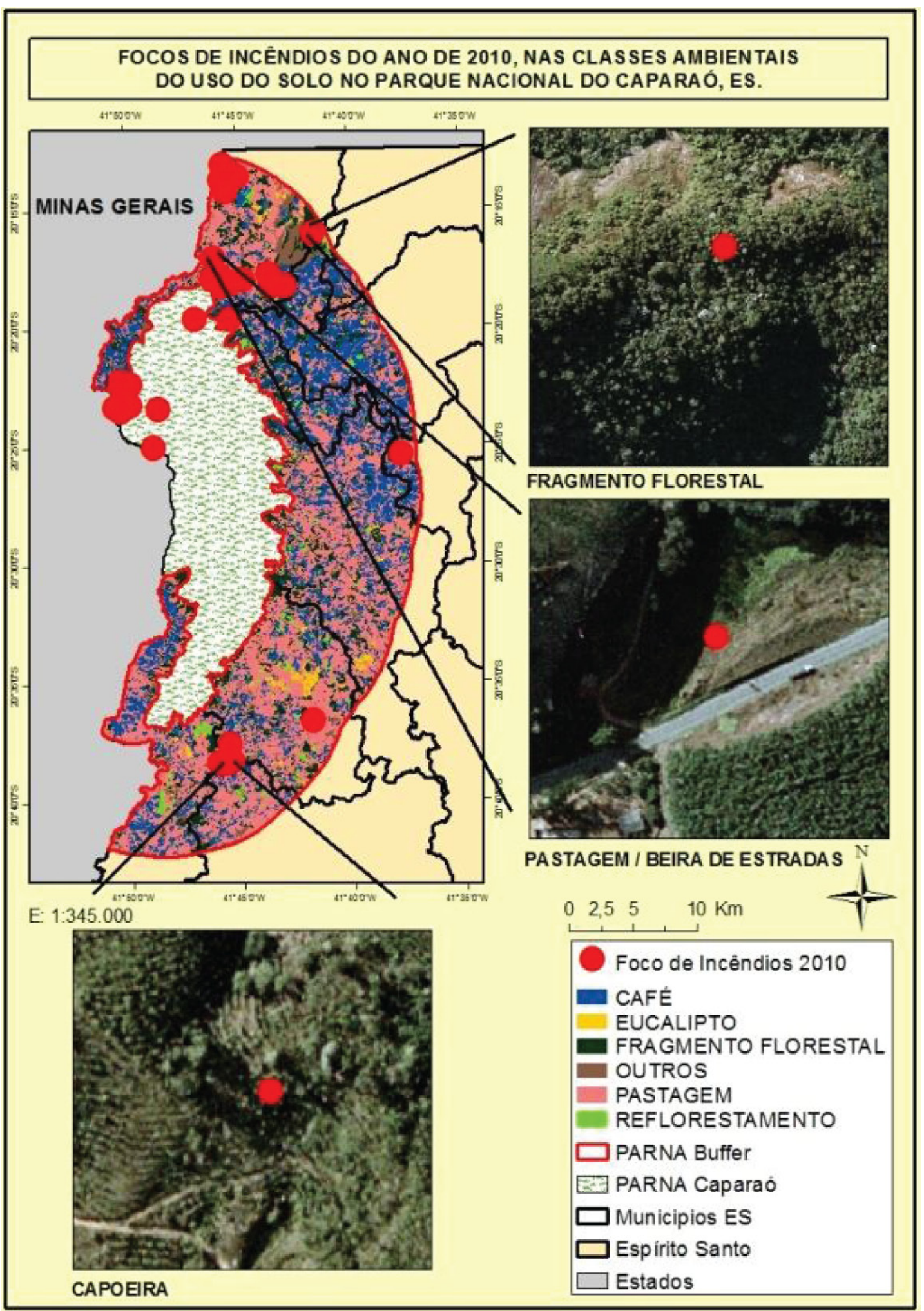

Figura 6. Focos de calor detectados pelo INPE na zona de amortecimento do PARNA-Caparaó, face capixaba, em 2010.

Figure 6. Heat spots detected by INPE in the buffer zone of Caparaó National Park, capixaba side, in 2010. 
grande parte dos incêndios registrados no Brasil ocorreram para renovação de pastagens e nas proximidades de estradas.

Os resultados apresentados neste estudo assemelham-se aos de Marques \& Lopes (2007), que pesquisou a pluriatividade na mesorregião metropolitana de Curitiba. Segundo o autor, nas regiões onde as propriedades rurais são pequenas, com uso e ocupação da terra destinados principalmente à agricultura familiar, as práticas tradicionais podem influenciar na ocorrência de incêndios florestais. Isso porque nessas propriedades ainda é comum o uso do fogo para a limpeza dos terrenos e não são raros os casos em que o fogo foge do controle e se alastra para outras áreas, provocando incêndios florestais. Esse panorama indica que, basicamente, os incêndios ocorrem em função de fatores externos às áreas florestais e devido à ação antrópica (Soares \& Batista, 2007; Prudente \& Rosa, 2010).

No Brasil, a maioria dos incêndios florestais nas Unidades de Conservação, no período seco, é de origem humana. Segundo o Ministério do Meio Ambiente (Brasil, 2010), essa situação ocorre por causa das mudanças no uso da terra, com a conversão de florestas em áreas agrícolas, aliada à utilização do fogo de forma não controlada. O uso incorreto do fogo como ferramenta de manejo agropecuário para renovação de pastagens, queima de restos culturais para preparação de plantio, controle de pragas e de ervas daninhas, eliminação de material lenhoso resultante de desmatamento, entre outros, nas propriedades vizinhas às Unidades de Conservação constitui importante causa de incêndios florestais (Medeiros \& Fiedler, 2004; IBAMA, 2009; Brasil, 2010). Medeiros (2002) afirma que os agricultores fazem a queima em período inadequado, não verificam as condições climáticas, não fazem aceiros e não têm conhecimento sobre equipamentos de controle do fogo e de métodos alternativos ao uso de queimadas.

Incêndios florestais em Unidades de Conservação constituem uma grave ameaça à conservação da biodiversidade e à manutenção de processos ecológicos. Os incêndios são particularmente graves em áreas pequenas, em áreas isoladas por cidades ou por monoculturas agrícolas, em ecossistemas sensíveis ao fogo e em áreas com espécies raras e/ou ameaçadas de extinção. Muitas Unidades de Conservação no Brasil apresentam uma ou mais dessas características vulneráveis (Medeiros \& Fiedler, 2004). As propriedades localizadas no território do Caparaó têm pequeno porte, a grande maioria com menos de 10 ha de área (Gobbo et al., 2015).

O conhecimento das classes de uso e ocupação das terras no entorno de APP e de Unidades de Conservação é fundamental para a avaliação do risco de incêndio, para a compreensão de como o incêndio se propaga e para a tomada de decisão em relação ao manejo do fogo (Ferraz \& Vettorazzi, 1998; Brasil, 2006). Segundo Ferraz \& Vettorazzi (1998) e Brasil (2010), o tipo de vegetação existente no local, a umidade da vegetação, a presença de restos vegetais no solo, a inclinação do terreno, o clima local e as faces de exposição do terreno em relação aos pontos cardeais são fatores que afetam a ocorrência e a propagação de incêndios florestais.

Pastagens têm combustibilidade alta, enquanto a mata nativa tem combustibilidade média. Portanto, as áreas de pastagem apresentam maior risco de ocorrência de incêndio (Ferraz \& Vettorazzi, 1998). O fogo depende da densidade e da altura das gramíneas que, quando secas, constituem o principal combustível (Prudente \& Rosa, 2009). Um pasto queima mais depressa do que uma floresta e um pasto seco queima mais depressa do que um pasto verde. Em relação aos restos vegetais no solo, quanto maior a quantidade e compactação, maior o esforço exigido para a quebra da continuidade do incêndio. Porém, pelo menor teor de oxigênio no solo, esse combustível tende a se queimar mais lentamente (Brasil, 2010).

As áreas com declividade mais acentuada apresentam maior risco de propagação do fogo. Quanto às faces de exposição do terreno, as áreas que recebem maior luminosidade, provocando o aquecimento da vegetação, têm maior risco de ocorrência de incêndios, enquanto áreas com maior incidência de ventos têm maior capacidade de propagação do fogo (Ferraz \& Vettorazzi, 1998).

No território do Caparaó, o relevo acidentado determina diferenças de temperatura entre as áreas mais baixas e mais altas. Nas áreas mais baixas, a temperatura pode chegar a $36{ }^{\circ} \mathrm{C}$ (ICMBio, 2015), o que aumenta o risco de ocorrência de incêndios. Como existem áreas com grande declividade, o risco de propagação do fogo das áreas mais baixas para as áreas mais altas também é grande.

Ações que podem ajudar a reduzir o risco de incêndio no Parque Nacional do Caparaó e em outras 
Unidades de Conservação são apresentadas por Medeiros \& Fiedler (2004), Brasil (2006) e IBAMA (2009). Destacam-se, entre elas, o plantio espécies vegetais com capacidade de armazenar água nas áreas limítrofes, formando aceiros naturais, visando o aumento da umidade relativa do ar; a construção de torres de observação em pontos estratégicos; a realização de um trabalho educativo, em parceria com escolas, associações e proprietários rurais, objetivando sensibilizar e esclarecer a comunidade sobre a necessidade e importância da prevenção dos incêndios florestais, a divulgação exaustiva de informações relativas aos perigos dos incêndios florestais e a realização da queima controlada, no entorno, autorizada e monitorada pelos órgãos ambientais.

A proteção do parque deve estar sempre associada à melhoria da produção e aos cuidados com o meio ambiente, buscando reduzir as perdas causadas pelo mau uso do fogo, tanto nas áreas agrícolas como nas florestais (Brasil, 2006). Medeiros \& Fiedler (2004) recomendam, ainda, o desenvolvimento de estratégias de combate aos incêndios e de um programa de monitoramento das atividades, por meio de pesquisas e de procedimentos técnicos, o que foi feito neste trabalho.

\section{CONCLUSÕES}

A fotointerpretação das classes ambientais de uso e ocupação da terra abrangeu uma área de 654,95 km², com $7,85 \mathrm{~km}^{2}$ de eucalipto, $89,03 \mathrm{~km}^{2}$ de fragmentos florestais, $314,31 \mathrm{~km}^{2}$ de pastagens, $13,01 \mathrm{~km}^{2}$ de reflorestamento, $180,42 \mathrm{~km}^{2}$ de café e $49,71 \mathrm{~km}^{2}$ ocupados por outros usos e ocupações.

O município de Iúna apresentou maior área de fragmentos florestais, com 27,85 km², Ibitirama apresentou maior área de pastagens, com 85,07 km², e o município de Divino de São Lourenço apresentou maior área de eucalipto e reflorestamento, com 3,36 e $3,27 \mathrm{~km}^{2}$, respectivamente.

Há uma área maior ocupada por reflorestamento nos municípios da zona de amortecimento do Parque Nacional do Caparaó, face capixaba, quando comparada a outros estudos.

Os focos de calor, em sua maioria, aconteceram em beiras de estradas, pastagens, capoeiras e próximo a fragmentos florestais.

\section{STATUS DA SUBMISSÃO}

Recebido: 22 ago., 2014

Aceito: 15 mar., 2016

\section{AUTOR(ES) PARA CORRESPONDÊNCIA}

\section{Fernando Coelho Eugenio}

Departamento de Ciências Florestais e da Madeira, Universidade Federal do Espírito Santo - UFES, Av. Governador Lindemberg, 316, CEP 29550-000, Jerônimo Monteiro, ES, Brasil e-mail: coelho.fernando@yahoo.com.br

\section{REFERÊNCIAS}

Almeida MAP. Indicadores de salubridade ambiental em favelas urbanizadas: ocaso de favelas em áreas de proteção ambiental [tese]. São Paulo: Departamento de Engenharia de Construção Civil, Escola Politécnica, Universidade de São Paulo; 2000.

Batista AC. Mapas de risco: uma alternativa para o planejamento de controle de incêndios florestais. Revista Floresta 2000; 30(1-2): 45-54.

Brasil. Ministério do Meio Ambiente - MMA. Instituto do Meio Ambiente e dos Recursos Naturais Renováveis IBAMA. Plano de prevenção, controle e combate aos incêndios florestais do Parna Caparaó e seu entorno. Brasília; 2006 [citado 2014 ago 22]. Disponível em: http://queimadas. cptec.inpe.br / rqueimadas/material3os/2006_Parna_ Caparao_manejofogo.pdf

Brasil. Ministério do Meio Ambiente - MMA. Instituto Chico Mendes de Conservação da Biodiversidade ICMBio. Manual para formação de brigadista de prevenção e combate aos incêndios florestais. Brasília; 2010. 90 p.

Chuvieco E, Congalton RG. Aplication of remote sensing and geographic information systems to forest fire hazard mapping. Remote Sensoring of Enviromment 1989; 29(2): 147-159. http://dx.doi.org/10.1016/0034-4257(89)90023-0.

Dutra-Lutgens H. Caracterização ambiental e subsídios para o manejo da zona de amortecimento da Estação Experimental e Ecológica de Itirapina-SP [dissertação]. Rio Claro: Centro de Estudos Ambientais, Universidade Estadual Paulista; 2000

Environmental Systems Research Institute - ESRI. ArcGIS Professional GIS for the desktop: versão 10.1. Redlands; 2012.

Eugenio FC, Louzada FLRO, Santos AR, Moulin JV. Confronto do uso e cobertura da terra em áreas de preservação permanente da bacia hidrográfica do Rio Alegre no município de Alegre, Espírito Santo. Engenharia Ambiental 2010; 7: 110-126. 
Eugenio FC, Santos AR, Louzada FLRO, Pimentel LB, Moulin JV. Identificação das áreas de preservação permanente no município de Alegre utilizando geotecnologia. Cerne 2011; 17(4): 563-571. http://dx.doi.org/10.1590/S010477602011000400016

Ferrari JL, Santos AR, Garcia RF, Amaral AA, Pereira LR. Análise de conflito de uso e cobertura da terra em áreas de preservação permanente do IFES - Campus de Alegre, Município de Alegre, Espírito Santo. Floresta e Ambiente 2015; 22(3): 307-321. http://dx.doi.org/10.1590/21798087.042113 .

Ferraz SFB, Vettorazzi CA. Mapeamento de risco de incêndios florestais por meio de Sistema de Informações Geográficas (SIG). Scientia Forestalis 1998; (53): 39-48.

Fiedler NC, Merlo AM, Medeiros MB. Ocorrência de incêndios florestais no Parque Nacional da Chapada dos Veadeiros, Goiás. Ciência Florestal 2006; 16(2): 153-161.

Gobbo SDA, Garcia RF, Alvarez CR, Eugenio FC, Amaral AA. Caracterização sociocultural das propriedades rurais do entorno do Parque Nacional do Caparaó. Enciclopédia Biosfera 2015; 11(22): 83-99.

Instituto Chico Mendes de Conservação da Biodiversidade - ICMBio. Parque Nacional do Caparaó. Alto Caparaó; 2015 [citado 2015 mar 10]. Disponível em: http://www.icmbio. gov.br/parnacaparao/4-parque-nacional-do-caparao.html

Instituto do Meio Ambiente e dos Recursos Naturais Renováveis - IBAMA. Roteiro metodológico para a elaboração de plano operativo de prevenção e combate aos incêndios florestais - Prevfogo. Brasília; 2009. 43 p.

Marques LM, Lopes LAA. Pluriatividade na mesorregião metropolitana de Curitiba. Revista Paranaense de Desenvolvimento 2007; 28(113): 147-174.

Medeiros MB. Manejo de fogo em unidades de conservação do cerrado. Boletim do Herbário Ezechias Paulo Heringer 2002; 10(1): 76-89.

Medeiros MB, Fiedler NC. Incêndios florestais no Parque Nacional da Serra da Canastra: desafios para a conservação da biodiversidade. Ciência Florestal 2004; 14(2): 157-168.

Mendes CAB. Integração de modelos hidrológicos e sistemas de informações geográficas: fundamentos. Revista Brasileira de Recursos Hídricos 1996; 1(1): 47-66.

Moreira TR, Santos AR, Dalfi RL, Campos RF, Santos GMADA, Eugenio FC. Confronto do uso e ocupação da terra em APPs no município de Muqui, ES. Floresta e Ambiente 2015; 22(2): 141-152. http://dx.doi.org/10.1590/21798087.019012 .

Oliveira FS, Soares VP, Pezzopane JEM, Gleriani JM, Lima GS, Silva E et al. Identificação de conflito de uso da terra em áreas de preservação permanente no entorno do Parque Nacional do Caparaó, Estado de Minas Gerais. Revista Árvore 2008; 32(5): 899-908. http://dx.doi.org/10.1590/ S0100-67622008000500015.

Prudente TD, Rosa R. Detecção de incêndios florestais no Parque Nacional da Chapada dos Veadeiros e área de entorno. Caminhos de Geografia 2010; 11(35): 209-221.

Prudente TD, Rosa R. Geotecnologias aplicadas à análise de incêndios florestais no Parque Nacional da Chapada dos Veadeiros. In: Anais do XIV Simpósio Brasileiro de Sensoriamento Remoto; 2009; Natal. Natal: INPE; 2004. p. 2951-2958.

Santos AR, Louzada FRO, Eugenio FC. ArcGIS 9.3 Total: aplicação para dados espaciais. Alegre: CAUFES; 2010.

Setzer AW, Sismanoglu RA. Risco de fogo: metodologia do Cálculo: descrição sucinta da Versão 9. São Paulo: INPE; 2012.

Silva AAL. O uso do Geoprocessamento no mapeamento e identificação de áreas de risco de incêndios florestais, com ênfase na região do Parque Estadual do Itacolomi, Ouro Preto / MG [monografia]. Belo Horizonte: Departamento de Cartografia, Instituto de Geociências, Universidade Federal de Minas Gerais; 2004.

Sismanoglu RA, Setzer AW. Risco de fogo para a vegetação da América do Sul: comparação de duas versões para 2003. In: Anais do XIII Congresso Brasileiro de Meteorologia; 2004; Fortaleza. Fortaleza: Sociedade Brasileira de Meteorologia; 2004.

Soares RV, Batista AC. Incêndios florestais: controle, efeitos e uso do fogo. Curitiba: Ronaldo Viana Soares e Antonio Carlos Batista; 2007. 264 p. v. 1.

White BLA, White LAS, Ribeiro GT, Fernandes PM. Development of a fire danger index for eucalypt plantations on the northern coast of Bahia, Brazil. Floresta 2013; 43(4): 601-610. http://dx.doi.org/10.5380/rf.v43i4.30973.

Young CEF. Economia do extrativismo em áreas de Mata Atlântica. In: Simões LLS, Lino CF, editores. Sustentável Mata Atlântica: a exploração de seus recursos florestais. São Paulo: Senac; 2002. p. 173-183. 